\title{
AQUINAS AND NATURALISM
}

\author{
PAUL O'GRADY
}

Trinity College Dublin

\begin{abstract}
Aquinas's actual response to a naturalistic challenge at ST I.2.3 is one which most naturalists would find unimpressive. However, I shall argue that there is a stronger response latent in his philosophical system. I take Quine as an example of a methodological naturalist, examine the roots of his position and look at two critical responses to his views (those of BonJour and Boghossian). If one adjusts some of the problematical aspects of their responses and establishes a hybrid position on the epistemology and metaphysics of an anti-naturalistic stance, it turns out to be the position Aquinas himself takes on meaning and knowledge.
\end{abstract}

\section{AQUINAS’S RESPONSE TO NATURALISM}

Aquinas presents two objections to the existence of God in his celebrated five ways discussion. The first is the problem of evil, the second the problem of naturalism. As he states the second it sounds like an application of Ockham's razor, that is, a principle of intellectual parsimony. When causes fully account for something, we don't need to postulate more. But the natural world has natural causes and human intervention to explain all the phenomena contained in it, so no further cause is required. As Laplace would put it six centuries later 'we have no need of that hypothesis'. Aquinas's response is to argue that natural and human causation do not exhaust the causal story and one is led to a first cause which is unchanging and which of itself must be. The response connects directly to the corpus of the article, with its arguments for a first cause and with associated texts in the Summa Contra Gentiles and the Commentary on Aristotle's Metaphysics. But modern naturalists would 
not be moved by this dialectical strategy, since basic to their position is a methodological objection to the possibility of making such a move as Aquinas's. There is not the possibility of an appeal to a higher science than those exhibited in the natural sciences and various arguments are presented to make this case. Simply asserting that there is such a science would be met with disbelief. Michael Rea, in a recent book on naturalism, notes that the majority of contemporary philosophers (at least in the English-speaking world) are naturalists, although exhibiting a high degree of variegation in how they view it; 'it enjoys the lofty status of academic orthodoxy. ${ }^{1}$

Aquinas's views on the methods and nature of the sciences are contained in summary in ST question 1, in greater detail in his commentary on Boethius's De Trinitate and in the commentary on Aristotle's Posterior Analytics. ${ }^{2} \mathrm{He}$ endorses Aristotle's deductive method, defends a form of foundationalism, argues dialectically for the necessity of intellectual first principles, has a hierarchical conception of the sciences, distinguishes practical and speculative science, uses the idea of subalternated science, distinguished the formal and material aspects of scientific inquiry. Among the features I'd like to note includes the systematicity of his views. His account of cognition in the individual, the relation of sense to intellect, the different workings of the intellect, dovetail with the account of the differences between disciplines, but also with the way intellectual disciplines constitute habits of mind directed to the goals of human existence. Typically these issues are treated as distinct in subsequent discussions - indeed philosophy of science, epistemology, moral psychology and issues about human destiny are rarely considered together in contemporary academia.

The contemporary intellectual world is therefore less integrated than the one presented by Aquinas. But it also poses important challenges

\footnotetext{
${ }^{1}$ Michael Rea, World Without Design, Oxford, OUP, 2002, p. 1

${ }^{2}$ Following standard convention I shall refer to Aquinas's Summa Theologiae by part, question and article. His views on scientia are in ST Ia q.1. The notes in the Blackfriars edition, Vol.1 edited by Thomas Gilby, are extensive and useful. The English translation by Timothy McDermott of The Commentary on Boethius's De Trinitate is excellent, in Aquinas Selected Philosophical Writings, Oxford: OUP, 1993 pp. 1-50. For a good English translation of the Commentary on Aristotle's Posterior Analytics see that by Richard Berquist, Notre Dame: Dumb Ox Books, 2007.
} 
to the methodology used by him. Naturalism as a recognisable phenomenon clearly was a possibility considered by Aquinas, but it was the 19th century when it became a genuine contender as a worldview. The kind of skepticism about speculative reason exhibited by Hume, the advances in the physical sciences, the kind of ideology shown by Comte, all generated a momentum which flourished in the ideals of scientific philosophy expressed by Frege and Russell which were deepened and refined by Carnap and Quine. In this, Quine stands as a watershed. The development of cognitive science, the work of naturalists such as Dennett, the Churchlands, the Kitchers, Devitt, all flow from his conception of the lack of principled distinction between natural science and philosophical reason. This is a powerful current in contemporary philosophy and reverberates more broadly in the popular works of Dawkins and Dennett. So is Aquinas's work merely a chapter in the history of ideas or can it engage with contemporary naturalism? It seems to me that Aquinas has the resources to challenge some of the arguments of the naturalists and indeed various contemporary anti-naturalistic philosophers are developing positions which look curiously familiar to those who know Aquinas. In the following sections I shall discuss the naturalism of Carnap and Quine, especially in relation to the notion of analyticity, examine some responses to Quinean naturalism and then compare these to Aquinas's account of mind and language. His position is robust enough to work as a viable alternative to naturalism, and is not at all dissimilar to contemporary anti-naturalistic positions.

\section{CARNAP AND QUINE ON NATURALISM}

If Quine is the most influential theorist of naturalism in the latter part of the twentieth century, Carnap is the most important influence on him. Recent studies of Carnap emphasize the neo-Kantian constitutive aspect of his work and play down the simple-minded verificationist caricature popularized by Ayer. ${ }^{3}$ One can think of his work as a continuation of

\footnotetext{
${ }^{3}$ See for example Michael Friedman, Reconsidering Logical Positivism, Cambridge: Cambridge University Press, 1999; Alan Richardson, Carnap's Construction of the World: The Aufbau and Emergence of Logical Empiricism, Cambridge: Cambridge University Press, 1997; Michael Friedman and Richard Creath, The Cambridge Companion to Carnap, Cambridge: Cambridge University Press, 2007.
} 
the Neo-Kantian project to clarify the a priori aspects of inquiry in a linguistic register. ${ }^{4} \mathrm{He}$ was influenced by Frege to value formal language and the need for a perspicuous system of representation, believing that many problems of philosophy are spuriously generated by the illusions of language. Russell supplied him with the model of scientific philosophy, Wittgenstein with a linguistic account of logical truth and logical consequence. He was reacting against nineteenth century German Idealism, despairing that sentences such as 'The Absolute is identical with itself' could be clarified, argued about or given truth values. His early work was on the idea of space, making sense of the developments of relativity theory, followed by an attempt to work out rigorously, using the logic of Principia Mathematica, an account of sense knowledge on the model of Russell's Our Knowledge of the External World - this was The Logical Structure of the World (1927). Following this was a turn to the nature of logical and mathematical truth in The Logical Syntax of Language (1934). Carnap defended the use of linguistic rules to constitute logical calculi, developing notions of truth, consequence and proof relative to these languages. The task of the philosopher is to develop this formal apparatus, which first order workers in mathematics, applied logic, philosophy of science and the sciences in general would use. Central to this project is the idea of analyticity. An analytic proposition is one made true by the rules of the linguistic framework, a synthetic one is made true by the world. Philosophy has a clear method - the use of linguistic frameworks, translating and analysing unclear natural language notions into highly tooled artificial concepts which can be applied scientifically. Philosophy doesn't articulate truths about the world, but aids science in doing that. The constraints on the use of formal languages are pragmatic - what the working scientist finds congenial and helpful to use. A clear statement of this can be found in "Empiricism, Semantics and Ontology" (1950). ${ }^{5}$ Carnap's work has strands of empiricism, pragmatism and NeoKantianism woven together within the guiding principle of the linguistic

\footnotetext{
${ }^{4}$ See his own account of the roots of his work in "Intellectual Autobiography" in The Philosophy of Rudolf Carnap, Schilpp P. (ed.), La Salle, Open Court, 1963, pp. 3-84.

5 "Empiricism, Semantics and Ontology", Revue internationale de philosophie, vol. 4 no. 11, (1950), pp. 20-40. (Reprinted as Appendix A to Meaning and Necessity, 2nd. edn., Chicago: Chicago University Press, 1956).
} 
turn in philosophy. Unlike Wittgenstein's approach to language, Carnap was a technician, avoiding natural languages and seeing the core role of philosophy as the production of carefully honed linguistic frameworks which would facilitate the answering of those questions which can be answered, and the avoidance of those which cannot. But like Wittgenstein he thought that language leads one astray and that metaphysics is a linguistic fiction, mistaking the form of representation for the matter conveyed by that form.

Quine was an early advocate of Carnap's approach to philosophy, which seemed to fit well with American pragmatism. ${ }^{6}$ He gave lectures in Harvard in the mid-1930's defending the approach which took analyticity as central. His "Truth by Convention" of 1936 is typically read in the light of his subsequent repudiation of analyticity, but is better seen as still internal to the analyticity project, dealing with internal tensions in it. ${ }^{7}$ Particularly that paper probes the problem of how a notion of analyticity might ground logical truth without presupposing it. However, the main break comes with "Two Dogmas of Empiricism" (1950). ${ }^{8}$ There, Quine examines the different possible ways analyticity might be explicated and finds them all wanting. He is dubious about the notion of meaning, construed as sense. One can work with an idea of reference, or extension, but intensions are opaque. Ideas of conceptual containment are merely metaphorical. Carnap's use of linguistic rules is rejected as ad hoc. Definitions rely on pre-existing linguistic practice and cannot themselves explain that practice.

There's much interpretative debate about Quine's exact target and his purpose in this celebrated paper. ${ }^{9}$ It seems important to distinguish the

${ }^{6}$ Dear Carnap, Dear Van, Creath, R., (ed.), Berkeley: University of California Press, 1990.

7 "Truth by Convention", Philosophical Essays for A.N. Whitehead, Lee, O., (ed.), New York: Longmans, 1936, pp. 90-124. (Reprinted in The Ways of Paradox and Other Essays, New York: Random House, 1966, pp. 77-106).

8 “Two Dogmas of Empiricism", Philosophical Review 60, (1951), pp. 20-43. (Reprinted in From a Logical Point of View, Cambridge, Ma: Harvard University Press, 1953, pp. 20-46).

9 See for example, W.V. Quine "Two Dogmas in Retrospect", Canadian Journal of Philosophy, vol. 21 no. 3, (1991), p. 265-274; H. Putnam, “Two Dogmas Revisited” in Realism and Reason, Cambridge: Cambridge University Press, 1983. 
semantic question about how to make the analytic/synthetic distinction, from the epistemological question of the a priori/a posteriori distinction, from the metaphysical question of the necessary/contingent distinction. These are often elided, but they are distinct. Quine attacks the semantic distinction between analytic and synthetic, but as a way of challenging the epistemological distinction between a priori and a posteriori. Analyticity seems the only way to explicate the a priori. An a priori proposition is one justified independently of the senses - analyticity explains how this is so using linguistic rules. Hence by attacking the analytic-synthetic distinction, Quine also attacked the a priori/a posteriori. Indeed the necessary-contingent also fell, since logical necessity rested also on analyticity.

By attacking the sharp analytic-synthetic distinction and replacing it with the idea of a continuum - sentences which are very closely linked to observation and sentences far removed from observation - Quine presented a different conception of philosophy to what had gone before. There are no neutral pure observation sentences, there are no pure theoretical observation-free sentences. By being linguistic, observation sentences are contaminated by theory. By being part of our web of belief, logical, mathematical and general scientific beliefs are connected to observation. We are reluctant to alter logical and mathematical beliefs because of the knock-on effect, but this is in principle possible (for example dropping some of the classical logical laws in discussing quantum phenomena might make for more elegant theories). Quine has articulated a picture of knowledge which is empiricist, coherentist, pragmatist and most importantly naturalist. There is no first philosophy which either gives a foundation to science or clarifies it from without. Philosophy is part of the ongoing quest for truth, but has no special method which distinguishes it from other parts of that question - it is self-reflective science (including the humanities and social sciences in this characterisation of science). He repeats Neurath's image of the human quest for knowledge as akin to sailors on a ship who are forced to continuously use the ship to stay afloat, but who can replace broken bits one at a time. For Quine, everything is revisable, but only against a critical mass of stability.

This kind of naturalism is primarily methodological. The methods by which truth is acquired are those of science broadly construed. There is 
no pure a priori method which rivals that of science. Quine is a physicalist rather than a materialist. Physicalists accept the ultimate theory of the world to be that delivered by physics - so it is revisable and ongoing. Quine's actual ultimate ontology is something like a neo-pythagorean picture, where mathematical sets provide the most tractable account of the world. But if science licenced clairvoyance or immortal souls, then these would be incorporated into the ontology. To look for a grounding for science is to seek what cannot be given, there is no Cartesian bedrock. While there are many debates about the details of Quine's views ${ }^{10}$, this picture has proved enormously influential - pragmatic, fallibilist, fruitful in terms of the interactions of philosophers with psychologists, linguists, neurologists, biologists and so on. The contemporary explorations of consciousness which are multi-disciplinary are the fruit of such a view.

However, not everyone is sanguine about this development. Some worry about the further developments of Quine's work. For example there is the doctrine of the indeterminacy of translation, that there are no facts of the matter about meaning. There is Quine's famous dismissal of modal notions. His account of the mental is famously austere and behaviourist. Dennett mischievously defines the verb 'to quine' in his dictionary as to deny the existence of something obvious and important (self-consciously ironically, given Dennett's Quinean view of consciousness). ${ }^{11}$ I want to discuss two critical reactions to Quine's work. The first, from Laurence BonJour, worries that Quine presents a corrosive skepticism about reason; the second, from Paul Boghossian, worries that Quine presents an incoherent skepticism about meaning. Both suggest correctives to Quine. My argument is that there are problems with both of their positions, but adjusted and amalgamated they make an attractive response to Quine. However, this amalgam turns out to already exist and it is the position defended by Aquinas.

${ }^{10}$ See for example, R.F. Gibson, The Philosophy of W.V. Quine, Tampa: University of South Florida Press, 1982; C. Hookway, Quine, Oxford: Polity Press, 1987, A. Orenstein, W.V.O. Quine, Chesham: Acumen, 2002; G. Kemp, Quine: A Guide for the Perplexed, London: Continuum, 2006; P. Hylton, Quine, London: Routledge, 2007.

${ }^{11}$ See http://www.philosophicallexicon.com. He also defines "aquinas, n.pl. (from a-, not, and quine) Philosophers who refuse to deny the existence or importance of something real or significant". 


\section{REACTIONS TO QUINE}

Lawrence BonJour defended a robust conception of the a priori rooted in rational intuition against moderate and extreme empiricists in his In Defence of Pure Reason (1998). ${ }^{12}$ For him, Carnap counts as a moderate empiricist and Quine as an extreme one. Moderate empiricists have an attenuated account of the a priori and modal knowledge by their doctrines of analyticity and conventionalism, whereas extreme ones reject any notion of the a priori. BonJour challenges various accounts of analyticity used to underpin the moderate empiricist position. ${ }^{13}$ His fundamental problem is that the notion does not do the epistemological or metaphysical work required of it. Certain versions of it straightforwardly rely on a pre-existing account of logical truth (what he calls reductive accounts). Hence these cannot serve as explanations of logical truth. Other versions obfuscate and disguise their question-begging, relying on hidden appeals to the a priori or to necessity. He notes that conventionalism cannot explain logical truth (conventions are freely chosen, logic is not). Crucially he wonders about the very status of the moderate empiricist claim. Since it is not an empirical claim, is it therefore analytic and conventional? If so, what then is its dialectical force, since conventions are supposed to be harmless and noncontentious? Finding the moderate empiricist position unclear, unmotivated, and unimpressive, he turns then to the Quinean position.

It seems to him that Quine's rejection of analyticity is rooted in epistemology. Quine really wants to jettison the a priori, which he understands as defending the view that there are unrevisable true propositions. But BonJour wonders: why not allow for a fallible conception of the a priori? Consider complicated calculations. Anomalies occur, checking is carried out and the calculation is amended. Such a procedure is canonically a priori if anything is (since no empirical input is required), but is also corrigible. Given that Quine devotes much effort to attack unrevisability, BonJour seeks to separate the issue of the a priori (beliefs not justified by experience) from revisability. A different argument is to query the very status of the naturalistic claim. It can't be based on a priori

\footnotetext{
${ }^{12}$ Lawrence BonJour, In Defence of Pure Reason, Cambridge: CUP, 1998 (hereafter DPR)

${ }^{13}$ DPR, pp. $28 \mathrm{ff}$
} 
reasoning, on pain of contradiction, but if it rests solely on assuming that reason consists in adjusting one's beliefs to experience, it assumes its conclusion illegitimately.

In opposing Quine, BonJour defends the Aristotelian notion of nous, rational intuition (also defended by Russell). Part of his dialectical strategy is to dismiss alternative accounts. His positive account relies on the phenomenology of cases where one considers a fundamental logical or conceptual truth, and 'sees' its validity. This is direct, immediate, non-discursive. It can be assimilated with the idea of 'true-in-virtue of meaning' - except here the epistemological work is being done by appeal to a faculty of reason rather than the conventionalism of the logical empiricists. BonJour argues that rational intuition of this kind yields insight into the nature of reality - the modal structure of the world. He explicitly acknowledges that this will require some account of intentionality in which concepts reflect the metaphysical structure of the world - and appeals to Aquinas as a model for such an account. I shall return to this below.

Paul Boghossian challenges Quine on different grounds, fearing that Quine's view results in a corrosive form of skepticism about meaning. Opposing Quine he defends a form of analyticity, articulating this position in his 1997 paper "Analyticity". Boghossian distinguishes different kinds of analyticity. Frege-Analyticity is that which assumes pre-existing logical truth (like BonJour's reductive account). CarnapAnalyticity on the other hand doesn't rely on logical truth, but grounds logical truth itself. Boghossian holds that Quine's arguments are effective against Frege-Analyticity, but not Carnap-Analyticity. CarnapAnalyticity is a form of implicit definition, where the meanings of the terms are defined in use. But what of the conventionalism and antirealism typically associated with such views? One sets up such definitions by social decision (conventionalism) and so it seems to be anchored in social practice rather in 'the world' (anti-realism). Boghossian denies that a defender of an implicit definition has to be necessarily committed to such views. Against conventionalism Boghossian holds the view that certain inferences are found to be primitively compelling, for example modus ponens. There is not a conventional free for all, but our practices are rationally constrained - to go against them is to be irrational. Against anti-realism is his claim that what grounds these implicit definitions is 
reference to the logical objects which make such inferences valid. So, for example, the negation sign operates by referring to a certain kind of logical object, which governs the inferences we use. Whatever the details of Boghossian's exegesis of Quine and others, the position he defends is one which appeals to metaphysical objects to ground logical inference and to the reference relation as the link between mind and world. There is genuine a priori knowledge available through reflection on the conditions of meaning. He dismisses the approach to the a priori which relies on rational intuition as mystificatory and 'flash-grasping.

BonJour and Boghossian have a number of things in common. They think that Quine's naturalistic position ends up in skepticism (about reason and about meaning, respectively). They believe there is genuine substantive a priori knowledge possible. A priori knowledge is realist, in that it connects up with the deep metaphysical structure of reality. They differ in their accounts of that deep metaphysical nature - BonJour being broadly Aristotelian and Boghossian being Platonist. They also differ in the mode of access to this reality. BonJour relies on rational intuition. Boghossian relies on basic inferential practices which confer meaning on the syncategorematic terms of our sentences. Boghossian is dismissive of rational intuition, relying on the Wittgensteinian notion of practice and the un-Wittgensteinian notion of logical object. ${ }^{14}$

The weak element of BonJour's case is the raw appeal to rational intuition which seems pre-linguistic and mystificatory. In a symposium discussion of his work this is a challenge which recurs - including a contribution by Boghossian. ${ }^{15}$ The weak element in Boghossian's position is the ad hoc nature of his Platonism, the appeal to logical objects (and he faces the standard objections to metaphysical Platonism). So, perhaps a response to Quine is possible in which a) rational intuition is drawn closer to language and practice, and b) where the account of reference of basic logical terms is not Platonized? It seems that Aquinas's account of meaning supplies exactly this.

${ }^{14}$ Wittgenstein described as the Grundgedanke (fundamental thought) of the Tractatus the claim that the logical connectives were not referring expressions - 4.0312.

${ }^{15}$ Book Symposium on BonJour's In Defense of Pure Reason in Philosophy and Phenomenological Research, 63 (3) (Nov 2001), p. 625ff 


\section{AQUINAS ON MEANING}

In this section I wish to outline the elements of Aquinas's account of meaning, discuss how synonymy and analyticity can be accommodated within it, show how the basic explanatory work about conceptual connection is being done by real natures with their modal properties and draw comparisons with the views of BonJour and Boghossian.

Aquinas inherits the Aristotelian account of the relationship of language, mind and reality. ${ }^{16} \mathrm{~A}$ significant feature of this account is the linking together of semantics and cognition - the story about meaning is internally connected to the story about knowing and cannot be treated independently of each other. It is also a realist account, in that mind and world are closely connected, problems about piercing the veil of appearance, knowing other minds and skepticism about the external world do not arise. As in Putnam's brain in the vat challenge to skepticism, the conditions of meaning are intrinsically connected to the way the world is, such that skepticism cannot even be clearly articulated. ${ }^{17}$ Hence a root assumption is that things in the environment of the thinker are capable of being known by her. Aquinas has a detailed account of how this happens, the details of which I shall pass over here. However, a key element in this account is that there is a metaphysical link between the structures which exist in the world and the person who knows them. That is, the forms which exist in the world come to exist in the soul of the person thinking about them. The same form exists in the world and in the thinker. He needs a psychological account of how this is possible and speaks of the passiones animae - the capacities in the soul and the processes it undergoes which allows for this kind of cognition. The process by which the soul grasps intelligible content from its environment is intellectus, a precondition for the further process of making propositions (compounding or dividing) called ratiocinatio. ${ }^{18}$

The relationship between the passiones animae and the forms in objects is natural and universal. It is a basic recognitional capacity which

${ }^{16}$ For a thorough discussion see John P. O'Callaghan, Thomist Realism and the Linguistic Turn, Notre Dame: University of Notre Dame Press, 2003, ch. 1.

${ }^{17}$ See Reason, Truth and History, Cambridge: Cambridge University Press, 1981, ch. 1.

${ }^{18}$ For a clear statement of this see the 'Prooemium' to the Commentary on Aristotle's Posterior Analytics. 
allows us to identify and individuate objects in our environment. But the use of names is conventional. Natural languages associate labels with passiones animae, by the process of imposition. So in any situation where I recognise, say, a cat, there is a natural psychological process by which I recognize the kind of thing it is and a simultaneous conventional element where I have been trained to associate a word with that recognition. The temptation here is to think of this as a three-part process. The thing in the world causes a passio animae, which is then labelled by the word. Classical empiricism had such an account in the theory of ideas, which existed as a representational third realm between mind and world. Such ideas seem to be in a realm of natural private language which is then translated into communicable public languages. Aquinas isn't committed to either a third realm or to private language. He says 'words refer to the things they signify through the mediation of a conception in the intellect. ${ }^{19}$ The crucial word here is 'ratio' - conception. This is the intelligible content of the thought held by the thinker. It is the means by which the object in the world is thought by her. There are two elements in cognition - the object cognized and the cognizer. The alteration to the cognizer caused by the apprehension of the object has a kind of character, a way of being thought about. This is the ratio - so it is not a third thing itself, but rather is the way by which the cognizer grasps the thing known. The way in which a knower develops in cognition can parallel the grasp of natural language in the way developmental psychologists tell us. Knowledge is socially inculcated, involving training in recognizing and naming, with no need to postulate a private language. So knowing that the meaning of a term is linked to our capacity to recognize things in the world, doesn't entail the existence of mysterious mental items as a third realm between entities and minds and doesn't require a private language.

A key concept in explicating the notion of meaning for Aquinas is significatio. As P.V.Spade says, this notion is a causal psychological term of art. ${ }^{20}$ Signification relates to the way in which things in the environment are knowable to the cognizer. Things in the environment exert a causal influence on the knower which leads to psychological

\footnotetext{
${ }^{19}$ ST Ia q.13 a.1

${ }^{20}$ P.V. Spade 'The Semantics of Terms' in The Cambridge History of Later Medieval Philosophy, N. Kretzmann, A. Kenny, J. Pinborg (eds), Cambridge: CUP, 1982.
} 
change. Of course, causal here has multiple meanings. There is an element of efficient causation in terms of Quinean impingements on our sensory surfaces - but even that basic level is shot through with notions of formal causation - the transfer of formal structure from object to medium to sense to intellect. The signification of a term is expressed in the ratio. Hence signification has to do with the realm of form, essence, intelligible content.

A further term is suppositio, which is typically translated as reference. Standard accounts in the 13th century distinguished various kinds of supposition a term might have. ${ }^{21}$ Aquinas doesn't engage with this detailed kind of distinction making, but does note an important way in which the supposition of subject and predicate terms differ from each other. ${ }^{22}$ A noun in a subject place typically supposits, or stands for, an individual and so is concrete in its supposition. The predicate is held to operate more like a verb and so supposits some abstract quality which is applied to the subject. Thus the predicate typically supposits in an abstract way, requiring that there be a subject in which the quality inheres. By distinguishing the different modes of signification of subjects and predicates Aquinas can avoid the danger of Platonism, the hypostasizing of abstract qualities as concrete individuals - good conceptual therapy in the manner of Carnap or Wittgenstein.

The distinction between res significata and modus significandi does a lot of work for Aquinas. The res significata is typically the extra-mental object. The modus significandi is the way in which this is referred to in language. The same res may have different modi significandi, which includes both the conventional linguistic term and the universal passio animae associated with it. This distinction allows him to make intelligible, for example, the doctrine of divine simplicity - where a metaphysically simple reality is referred to using different modi significandi, yielding genuine, contentful, non-synonymous information about it. With this sketch in place of Aquinas's views on the conditions of meaning, let's now turn to questions about analyticity, modality and the a priori.

${ }^{21}$ See, for example, Lambert of Auxerre's work, in The Cambridge Translations of Later Medieval Philosophical Texts, vol. 1, Norman Kretzmann and Eleanor Stump, (eds), 1988, p. $102 \mathrm{ff}$.

${ }^{22}$ ST Ia q.13a.12 
Quine makes a significant statement in "Two Dogmas of Empiricism", when he asserts that meanings are what essences became when wedded to the word. ${ }^{23}$ This is to dismiss meanings, since essences were clearly outré for him. However, after Putnam and Kripke it is once again respectable to allow real natural kinds with their own metaphysical natures which exert a causal influence on meaning. And meanings, rather than being free-floating conventions constituted by linguistic fiat, are shaped and governed by the deep structures of the things they are connected to. The conventional element is there in natural languages, but also nonconventional elements in our thinking about them, fixed by the real features of objects.

Aquinas discusses the ways in which subjects and predicates relate to each other in sentences. In some sentences there is an internal connection between subject and predicate, such that the ratio of the subject involves the ratio of the predicate. Recall that the ratio is the intelligible content of the term and that this is fixed by the real nature referred to. So whether the subject and predicate are linked or not is fixed by the world. Subjects may necessarily involve the predicate - if they are involved in their definition. Scott MacDonald usefully points out that definitions are not primarily linguistic, but are real structures in reality which get expressed linguistically. ${ }^{24}$ Thus, for Aquinas, scientia or knowledge is both a propositional attitude of individuals and an objective set of propositions matching the real structure of the world. When in a sentence a subject includes its predicate within itself, this is a real, necessary, feature determined by the nature of the entity. If it excludes it this is also a necessary feature. Otherwise, there is a contingent connection between subject and predicate. (Note that this is not simply the distinction between substantial and accidental prediction, since there can be necessary accidents.)

Also, there is a robust distinction drawn between the order of knowledge and the order of being. Whether or not subjects are necessarily connected to predicates holds whether or not this is known to us. So some propositions may be self-evident in themselves, in that the predicate is

\footnotetext{
${ }^{23}$ W.V. Quine, "Two Dogmas of Empiricism”, p. 22.

${ }^{24}$ See Scott MacDonald, "Theory of Knowledge" in N. Kretzmann and E. Stump (eds), The Cambridge Companion to Aquinas, Cambridge: Cambridge University Press, 1993.
} 
objectively included in the subject, but unknown to us. Aquinas believes that God's existence is of this kind. God's existence is necessary and if we knew God's essence we would see this, but God's essence is in principle inaccessible to us. Knowledge of some necessary connections is yielded by empirical research into the real features of things - for example that water is $\mathrm{H} 2 \mathrm{O}$. Other necessary connections are revealed by reflection and dialectic and so are gained in an a priori fashion, but always rooted in a connection to real kinds.

Logical and mathematical knowledge is also necessary, but traces the connections between mental conceptions, or second intentions. But even these are rooted in the real metaphysical features of reality. The principle of non-contradiction, which is fundamental to our reasoning, relies on the non-compossibility of contradictories. This rests on the impossibility of being and not-being in the same respect at the same time. This principle cannot be argued for demonstratively on pain of circularity, but can be defended by showing the absurdity of denying it. So, necessary connections exist as a real feature of the concrete individuals of distinct kinds in the world. Necessary connections also exist in our thought about them insofar as our thought faithfully mirrors those real features and in the structural features of our thought, logic and mathematics. Thus the explanatory bedrock for Aquinas is his account of real kinds in reality which exhibit modal properties in themselves. Thought tracks these structures to the extent it can and the language we use reflects these structures. Analytic propositions are those whose subjects and predicates are connected by virtue of relations of second intention - logical and mathematical relations. Synthetic propositions are those whose subject and predicate are connected by relations of first intentions, relations of real kinds. Knowledge of the former is always by reflection. The latter may be by reflection or by empirical inquiry.

Thus, Aquinas gives a way of making the analytic-synthetic distinction, explains conceptual containment by reduction to real definitions and gives an account of intentionality based on formal identity. He avoids conventionalism and gives a realist grounding to definition, synonymy and linguistic usage. Like BonJour he appeals to rational intuition and defends it both through appeal to phenomenology and dialectically. But he also connects the cognitive grasp of logical primitives with their linguistic usage. Thus the direction of explanation is from intellect 
to behaviour. Our primitive logical apparatus tracks genuine truthpreserving features exhibited by the formal aspects of thought. He is akin to Boghossian in treating language as important, but connecting it to cognition and avoiding platonistic metaphysics.

Opposition to this approach comes by claiming it is mystificatory. ${ }^{25}$ Without the background conceptual scheme of a metaphysics using form and formal causation the story doesn't make a lot of sense - and such a conceptual scheme isn't very prevalent in contemporary discussions. However, recent work by John O'Callaghan and Jonathan Jacobs serves to make one reconsider the theoretical resources of such a position. O'Callaghan analyses and defends Thomas's semantic triangle and argues for its strength. ${ }^{26}$ Jacobs argues that Aquinas's concept externalism has the resources for a non-skeptical solution to such issues as Quine's thesis of the indeterminacy of translation, Goodman's grue paradox and Kripke's plus-quus paradox. ${ }^{27}$ In each case the puzzle arises about how to explain normativity about concept use and Jacobs argues that Aquinas avoids the skeptical pitfalls. Such engagements seem fruitful, working out in detail the ways in which Aquinas's position can tackle certain kinds of contemporary challenge.

\section{CONCLUSION}

I began by saying that Aquinas's response to the problem of naturalism is to restate his account of the hierarchy of sciences and the need for metaphysics and that such a response would be underwhelming to naturalists. What I hope to have shown is that contemporary naturalism grew out of a debate about conceptual relations and a cluster of debates about linguistic rules, the foundations of logic and the relationship of language to the world and that Aquinas's views on these issues are germane to contemporary debates. Given his basic commitments to realism, natural kinds and externalism about mental content, his work can be seen

\footnotetext{
${ }^{25}$ See for example the discussion in Philosophy and Phenomenological Research, vol. 63, no. 3 (Nov 2001), p. $625 \mathrm{ff}$.

${ }^{26}$ See O’Callaghan op. cit. passim.

${ }^{27}$ Jonathan Jacobs, "Habits, Cognition and Realism" in John Haldane (ed.), Mind, Metaphysics and Value in the Thomistic and Anaytical Traditions, Notre Dame: University of Notre Dame Press, 2002, pp. 109-124.
} 
as genuinely engaging with the type of philosophical problems central to contemporary discussion. His work has been relegated by those under the influence of Hume and Kant who reject such realism and externalism. Given the resurgence of metaphysics in the analytic tradition, these kinds of objection to his work seem less cogent.

What then of Aquinas's project of arguing for God's existence? In this paper I have shown that his work on cognition, on conceptual relations and on the analytic-synthetic distinction provide important ways of challenging an objection to this project. Whether his actual arguments for God's existence are in any way plausible is another issue. But the burden of this paper is to undermine one influential objection to even considering such a question. 